\title{
Defect Prediction at the Superplastic Forming Process of the Bipolar Plate by Simulation
}

\author{
Ismi Choirotina ${ }^{\mathrm{a}}$, Moch. Agus Choiron ${ }^{\mathrm{b}}$. \\ ${ }^{a}$ Mechanical Engineering Department, Islamic University of Malang (UNISMA) \\ Malang, Indonesia \\ e-mail: ismichoirotin@yahoo.com \\ ${ }^{b, c}$ Mechanical Engineering Department, Brawijaya University \\ Malang, Indonesia
}

\begin{abstract}
Improper parameter setting at the bipolar plate forming by superplastic process will outcome damage to the final workpiece. By employing computer simulation, the defect at the bipolar plate could be predicted close to the maximum thickness reduction and the effective stress data. Simulate the fabrication of bipolar plate by a number of forming temperature $\left(350-450{ }^{\circ} \mathrm{C}\right)$ and air pressure $(0.25-1 \mathrm{MPa})$ utilize Ansys, resulting maximum thickness reduction and effective stress occurred at $450{ }^{\circ} \mathrm{C}$ and $1 \mathrm{MPa}$. Make reference to the result, the bipolar plate didn't expose any deficiency with $36.75 \%$ maximum thickness reduction. Have recourse to simulation will abbreviate the trial and error method as of the production process will more effective and efficient in terms of time and cost
\end{abstract}

Keywords: bipolar plate; superplastic; metal forming; simulation

\section{INTRODUCTION}

Fuel Cell is a kind of the renewable energy sources which developed due to its high efficiency [1][3]. One of the most important components of the fuel cell is the bipolar plate. Bipolar plate was very important as its function as a part that produces the electricity and as a frame where the fuel cell stack. Moreover, the production cost of the bipolar plate was the highest comparing to another fuel cell components [4][5].

A metal bipolar plate was widely used regarding its superiority comparing to other material [2]. Numerous method developed to fabricate bipolar plate with precise shape and dimension, therefore fulfill the criteria to produce high-performance fuel cell. The sheet metal forming process has gradually replaced the past processing methods.

Superplastic metal forming was one of the methods employed to produce Bipolar Plate. Take the advantage of superplastic metal forming, has preeminence over other forming processes, e.g.: the absence of spring back effects, the low pressure required and qualified to produce the complex shape [6]. However, practically this superplastic forming process has several problems such as wrinkle, uneven thickness indeed broke or tear at the final result of the workpiece. This problem arises from inaccurate calculation of the material flow amount into the dies, whereupon at the superplastic forming process it depends on the heating temperature and the air pressure parameter setting.

Applied trial and error method to get the optimum parameter of a production process was costly and wasting time. The simulation method is the alternative methods used to obtain the optimum parameters of a production process economically and efficiently. To ensure the validity of the computer simulation results it have need to verify the result with the experimental output.

An experiment and computer simulation of the bipolar plate making with superplastic forming method have done, but this study only discusses the final dimension of the bipolar plate (depth of the micro flow channel) regardless the possibility of damage to the end result, where the optimum bipolar plate dimension reach at $450^{\circ} \mathrm{C}$ forming 
temperature and $1 \mathrm{MPa}$ forming pressure as shown in Figure1.1 [7]. This research will be an alternative method to predict the damage possibility of the bipolar plate, where the simulation results of the superplastic process will be compared with the experimental results.

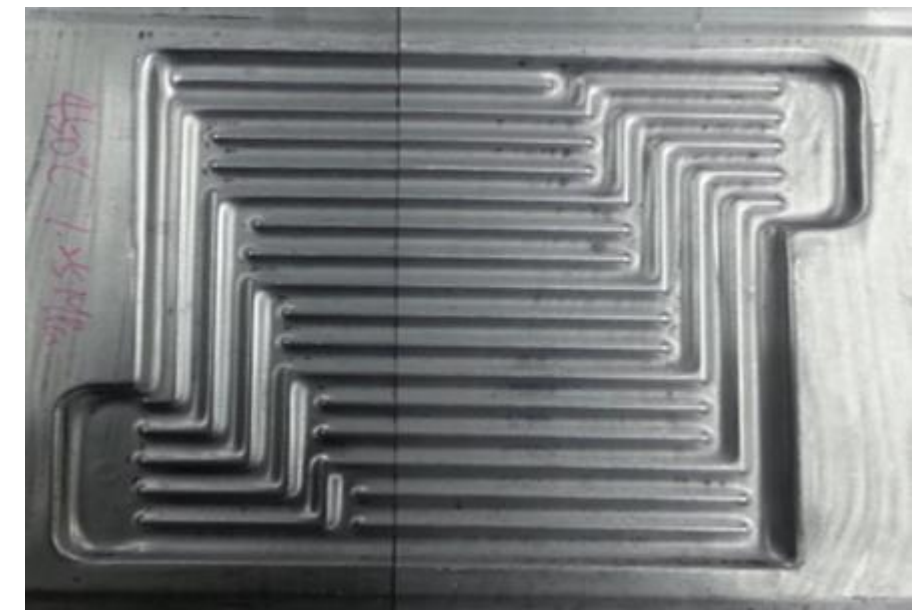

Figure 1.1 Experimental bipolar plate result at $450{ }^{\circ} \mathrm{C}$ forming temperature and $1 \mathrm{MPa}$ forming pressure [7]

\section{Methods}

ANSYS Academic version 18.0 software will be utilized to simulate the bipolar plate making by superplastic method. The expected final result was the absence of damage from the bipolar plate. The defect presence of the bipolar plate final result could be analysed through maximum thickness reduction and maximum effective stress data.

\subsection{Workpiece}

In this study used Aluminium Alloy A5052, which is modelled half of the actual conditions since its symmetry and simulation time savings. The workpiece dimension as below:
Length
$=180 \mathrm{~mm}$,
Width
$=146 \mathrm{~mm}$,
Thickness
$=0.5 \mathrm{~mm}$

The chemical composition and mechanical properties of Aluminum Alloy A5052 as shown on Table 2.1 and Table 2.2. [8]

Table 2.1. Aluminum Alloy A5052 chemical composition (\% Wt)

\begin{tabular}{lrrrrrrrr}
\hline Mg & Mn & Cu & Cr & Zn & Si & Fe & Other & Al \\
\hline $2.2-$ & $<0.1$ & $<0.1$ & $0.15-$ & 0.10 & $<0.25$ & $<0.4$ & $<0.15$ & RE \\
2.8 & & & 0.35 & & & & & \\
\hline
\end{tabular}

Table 2.2. Aluminum Alloy A5052 Mechanical Properties

\begin{tabular}{cccc}
\hline $\begin{array}{c}\text { Tensile Strength } \\
\left(\mathbf{N} / \mathbf{m m}^{2}\right)\end{array}$ & $\begin{array}{c}\text { Yield Strength } \\
\left(\mathbf{N} / \mathbf{m m}^{\mathbf{2}}\right)\end{array}$ & $\begin{array}{c}\text { Elongation } \\
(\%)\end{array}$ & $\begin{array}{c}\text { Fatigue Strength } \\
\left(\mathbf{N} / \mathbf{m m}^{\mathbf{2}}\right)\end{array}$ \\
\hline 260 & 215 & 10 & 125 \\
\hline
\end{tabular}

Source: A.S.M.I.H. Committee, ASM International, 1993 


\subsection{Superplastic Forming}

The scheme of superplastic forming process, as shown in Figure. 2.1, wherein (a) The workpiece called blank or sheet metal, placed between Punch and lower die and supported by the blank holder. Sheet metal was heated to a specified temperature, (b) Punch presses the sheet metal into the lower die, as well as close the pressure leak out, and (c) when the punch fully moved, the sheet metal was pressed by the pressurized gas and forced it to fill the lower die profile.
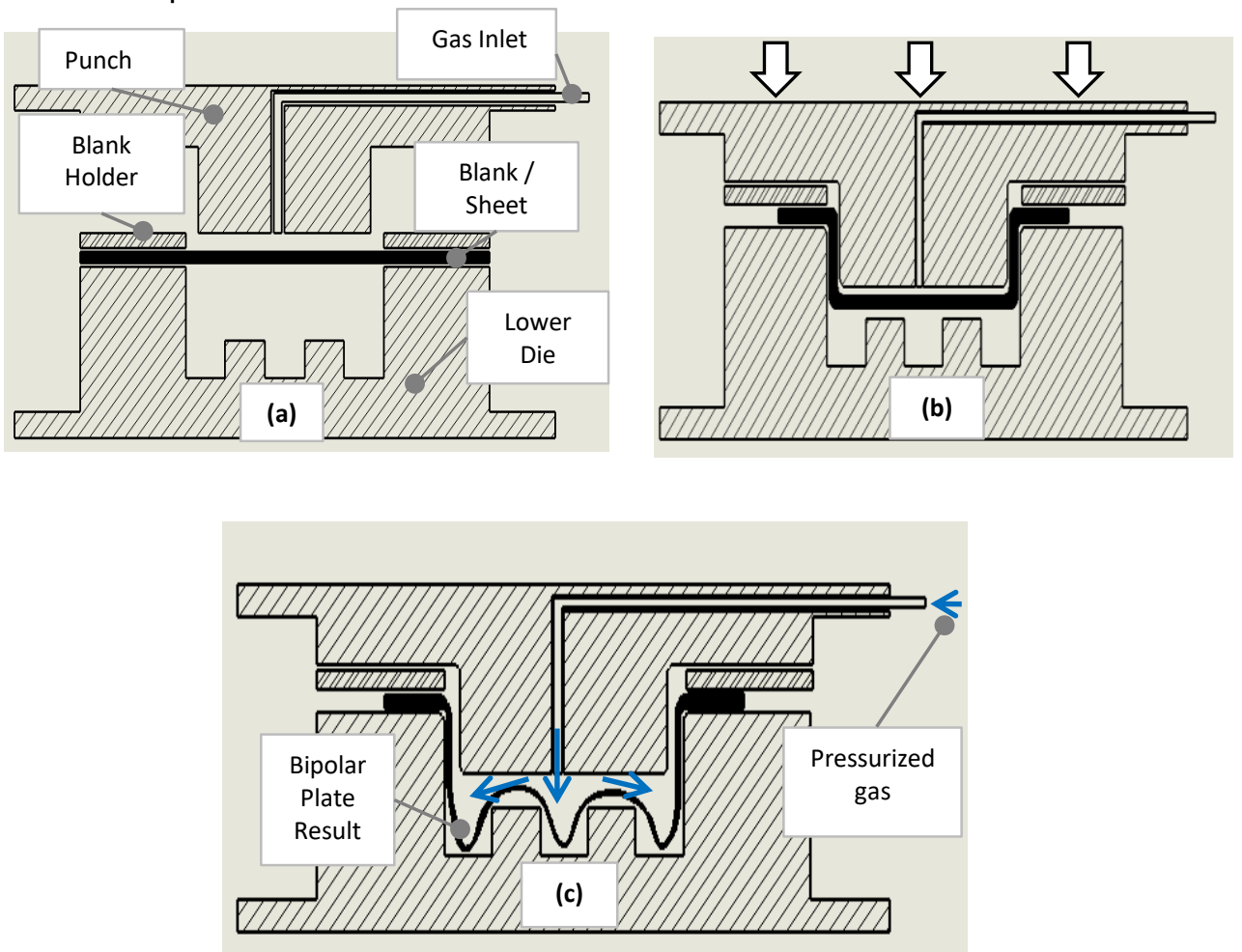

Figure 2.1 Superplastic forming scheme

\subsection{Simulation Setting}

Explicit finite element analysis with ANSYS 3D applied to simulate bipolar plate fabrication by superplastic forming. The dies material modelled as rigid material, while sheet metal modelled as sensitive rate power law material and Shell 163 element type. Deformation at high temperature are modelled by power law equation [9]:

$$
\sigma=K \varepsilon^{n} \dot{\varepsilon}^{m}
$$

Where,

$$
\begin{array}{ll}
\sigma & =\text { flow stress } \\
\varepsilon & =\text { effective strain } \\
\dot{\varepsilon} & =\text { effective strain rate } \\
K & =\text { material constant } \\
n & =\text { strain-hardening exponent } \\
m & =\text { strain rate sensitivity exponent }
\end{array}
$$

Material constant and strain rate sensitivity value are defined as each forming temperature. Forming temperature varied as $350,375,425$ and $450^{\circ} \mathrm{C}$ at $1 \mathrm{MPa}$ constant forming pressure, while forming pressure set as $0.25 ; 0.5 ; 0.75$ and $1 \mathrm{MPa}$ at $450^{\circ} \mathrm{C}$ fixed forming temperature. 


\section{ResUlt AND DISCUSSION}

The validation executes by comparing bipolar plate final dimension to the experimental result. The final dimension represented by the depth of the micro-flow channel gave the similar tendency both of experimental and simulation result with $2.3 \%$ average error rate. Build upon that result could be concluded that the simulation data was veritable and come up with the actual result.

Figure 3.1 exhibit the simulation result of bipolar plate making by superplastic process, at $450^{\circ} \mathrm{C}$ constant forming temperature. Graphic 3.1 shows the simulation outcome value, where the maximum thickness reduction at bipolar plate had increase as the forming pressure increments $(0.25-1 \mathrm{MPa})$, at $450^{\circ} \mathrm{C}$ constant forming temperature. That tendency occur since the forming pressure increase caused the effective stress increments. The effective stress during material yielding will be equal to the flow stress, by mean the material flow increments and large thickness reduction.

$450{ }^{\circ} \mathrm{C} ; 0.25 \mathrm{MPa}$

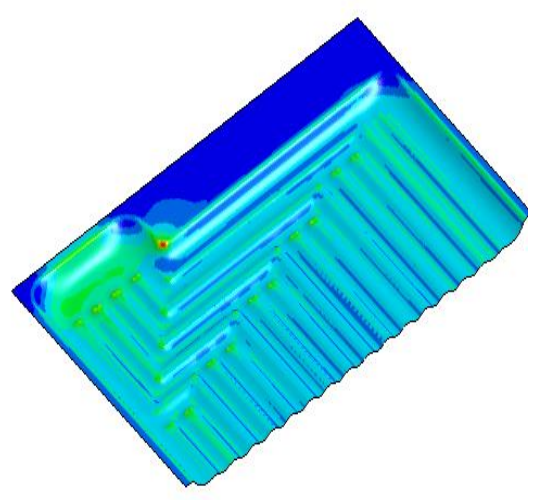

Fringe Levels

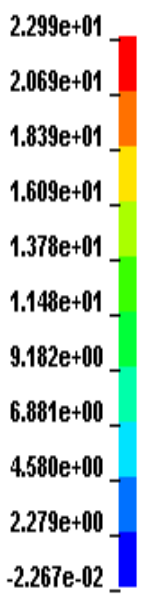

$450{ }^{\circ} \mathrm{C} ; 0.5 \mathrm{MPa}$

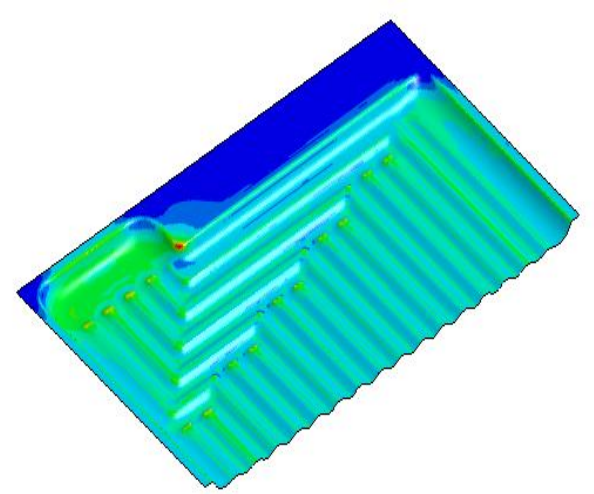

Fringe Levels

$2.854 \mathrm{e}+01$

$2.568 \mathrm{e}+01$

$2.282 \mathrm{e}+01$

$1.997 \mathrm{e}+01$

$1.711 \mathrm{e}+01$

$1.425 \mathrm{e}+01$

$1.140 \mathrm{e}+01$

$8.540 \mathrm{e}+00$

$5.684 \mathrm{e}+00$

$2.827 e+00$

$-2.938 \mathrm{e}-02$

Fringe Levels

$450{ }^{\circ} \mathrm{C} ; 1 \mathrm{MPa}$

$$
\begin{gathered}
\left.\begin{array}{c}
\text { Fringe Levels } \\
3.287 \mathrm{e}+01 \\
2.956 \mathrm{e}+01 \\
2.626 \mathrm{e}+01 \\
2.295 \mathrm{e}+01 \\
1.965 \mathrm{e}+01 \\
1.634 \mathrm{e}+01 \\
1.303 \mathrm{e}+01 \\
9.725 \mathrm{e}+00 \\
6.419 \mathrm{e}+00 \\
3.112 \mathrm{e}+00 \\
-1.941 \mathrm{e}-01
\end{array}\right]
\end{gathered}
$$

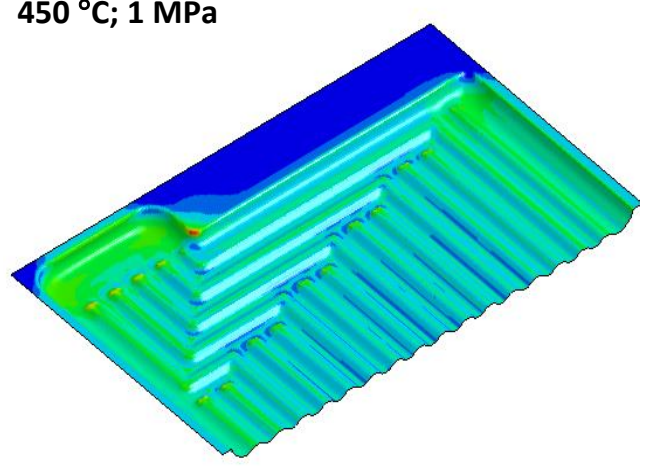

$3.675 \mathrm{e}+01$

$3.306 e+01$

$2.938 \mathrm{e}+01$

$2.569 \mathrm{e}+01$

$2.201 \mathrm{e}+01$

$1.832 e+01$

$1.464 \mathrm{e}+01$

$1.095 \mathrm{e}+01$

$7.267 \mathrm{e}+00$

$3.583 \mathrm{e}+00$

$-1.022 \mathrm{e}-01$

Figure 3.1 Thickness reduction plot at $450^{\circ} \mathrm{C}$ forming temperature simulation result 


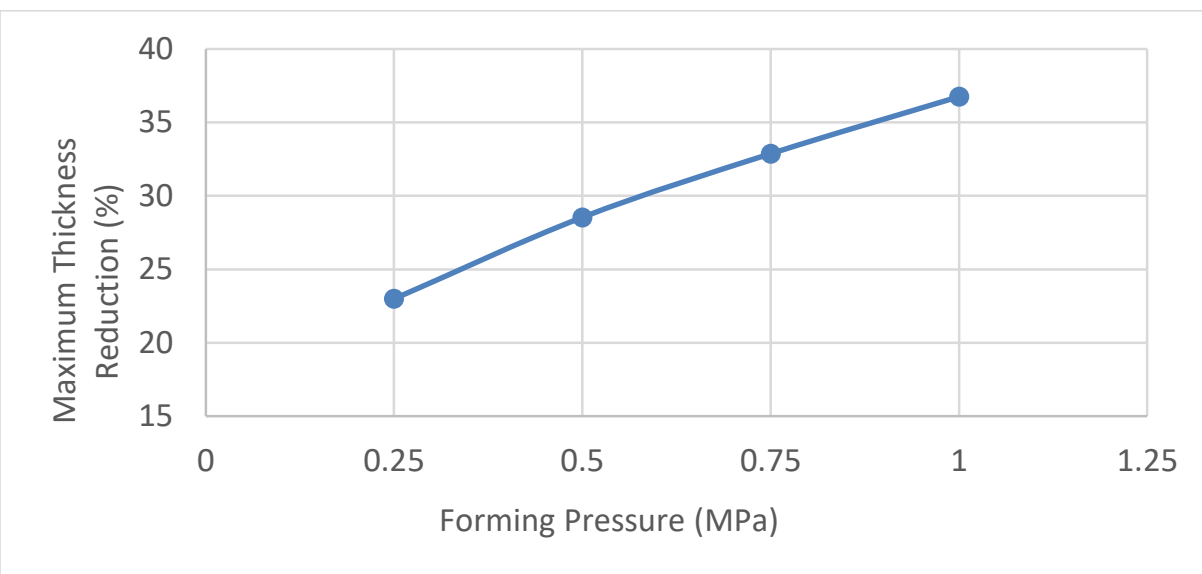

Graphic 3.1 Maximum thickness reduction at $450^{\circ} \mathrm{C}$ forming temperature

As well as the maximum thickness reduction had risen when the forming temperature increase $\left(350-450^{\circ} \mathrm{C}\right)$, at $1 \mathrm{MPa}$ constant forming pressure as indicate at Graphic 3.2. That phenomena happen due to the metal characteristic at high temperature, where the effect of strain rate become increasingly important determined flow stress value thus make the flow stress increased and reduce the bipolar plate thickness.

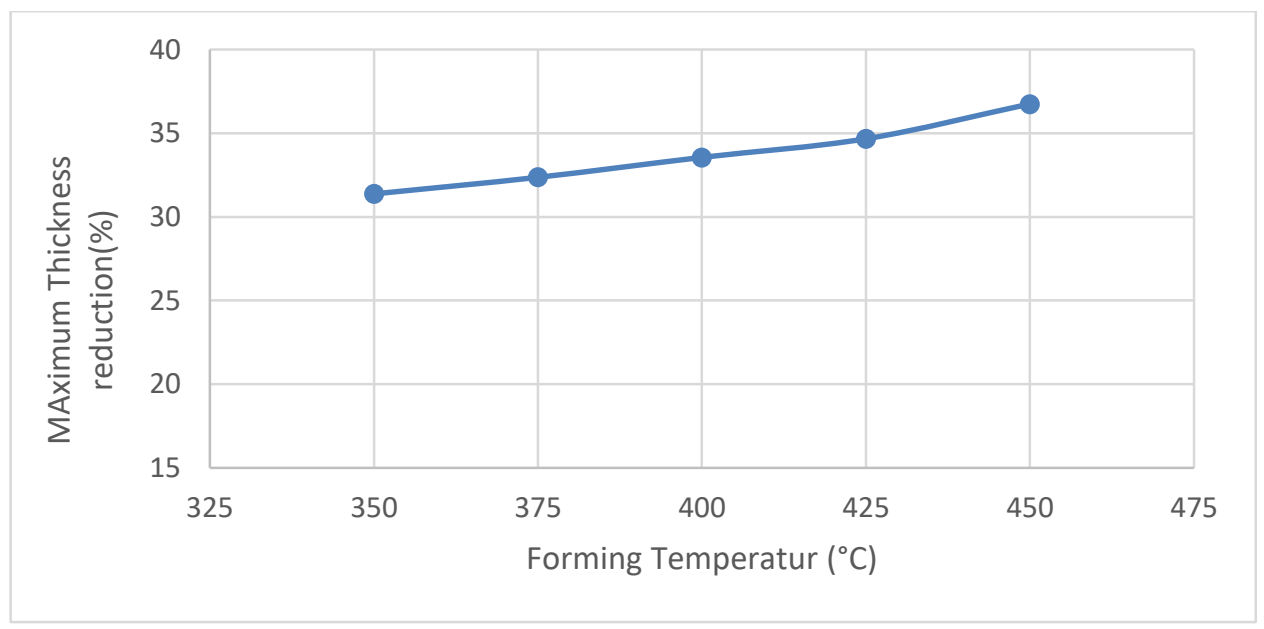

Graphic 3.2 Maximum thickness reduction at $1 \mathrm{MPa}$ forming pressure

Refer to the simulation result, there was no tear nor broken defect at maximum forming pressure and temperature setting, it was proved that the maximum thickness reduction only reaches $36.75 \%$ at $450^{\circ} \mathrm{C}$ and $1 \mathrm{MPa}$, as the hypothesis tear and broken defect will occur when maximum thickness reduction closed to $100 \%$.

The simulation exhibit that the maximum thickness reduction for each parameter setting, occur at the similar position as shown in figure 3.2. To analyze that phenomena, the maximum thickness reduction compared to the maximum effective stress and it was proven the maximum value took place at the common position (corner thinnest position). The corner thinnest occasion come about the dies profile makes the material flow as a tensile stress to multilateral direction that causes a large thickness reduction comparing to another position at the workpiece. 


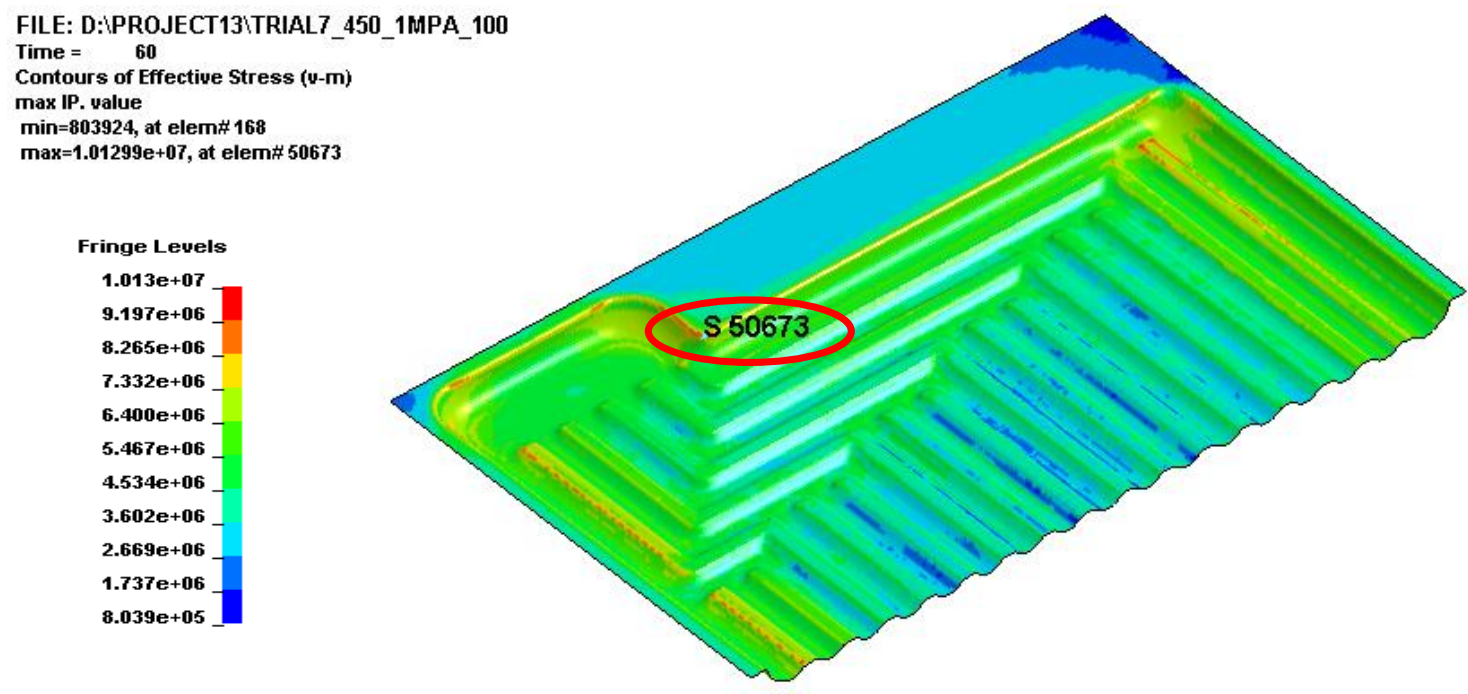

Figure 3.2 Effective stress plot at $450^{\circ} \mathrm{C}$ forming temperature and $1 \mathrm{MPa}$ forming pressure

\section{Conclusion} simulation result

Computer simulation methods not only utilized to predict the final dimensions of a process, but also can predict what defects will take place to the end result. To produce a bipolar plate with a certain dimension with superplastic process, which requires $1 \mathrm{MPa}$ forming pressure and $450^{\circ} \mathrm{C}$ forming temperature, it can be predicted that the parameter is safe in terms of the occurrence of tear and broken defects.

\section{REFERENCES}

[1] Bar-On I., Kirchain R., Roth R., Technical cost analysis for PEM fuel cells, J. Power Sources, 109 (2002), 71-75

[2] Tawfika H., Hung Y., Mahajan D., Metal bipolar plates for PEM fuel cell - A review, J. Power Sources, 163 (2007), 755- 767

[3] Hermann A., Chaudhuri T., Spagnol P., Bipolar plates for PEM fuel cells: A review, Int. J. of Hydrogen Energy, 30 (2005), 1297-1302

[4] Li X., Sabir I., Review of bipolar plates in PEM fuel cells: Flowfield designs, Int. J. of Hydrogen Energy, 30 (2005), 359-371

[5] Koç M., Mahabunphachai S., Feasibility investigations on a novel micro-manufacturing process for fabrication of fuel cell bipolar plates: Internal pressure-assisted embossing of microchannels with in-die mechanical bonding, J. Power Sources, 172 (2007), No. 2, 725-733

[6] N. Chandra, S.C. Rama, Z. Chen. Critical issues in the industrial application of SPFProces modelling and design practice. Materials Transactions, JIM. 1999; 40: 723736.

[7] Ismi C, Fabrication of micro-flow channel with AA5052 by low pressure superplasticlike forming, Taoyuan, National Central university - Brawijaya University, 2014.

[8] A.S.M.I.H. Committee, ASM International, 1993

[9] T. Altan, S.I. Oh, H.L. Gegel, Metal forming: fundamentals and applications, American Society for Metals, 1983 